\title{
Çocuklarda Herpes Zoster: 55 Olgudan Oluşan Retrospektif bir Çalışma
}

\author{
Sinan ÖZÇELIK \\ Balıkesir Üniversitesi Tıp Fakültesi, Deri ve Zührevi Hastalıklar Anabilim Dalı, Balıkesir.
}

\begin{abstract}
ÖZET
Herpes zoster, dorsal kök ganglionlarında latent halde bulunan varisella zoster virüsün reaktivasyonu ile ortaya çıkan bir enfeksiyondur. Herpes zoster nadiren sağlıklı çocukları etkiler. Herpes zoster tanılı pediatrik hastaların klinik ve demografik özelliklerinin araştırılması amaçlandı. Aralık 2014 ile Aralık 2016 tarihleri arasında hastanemiz Deri ve Zührevi Hastalıkları polikliniğine başvurmuş 16 yaş altı herpes zoster tanısı almış 55 hasta çalışmaya dahil edildi. Hastaların klinik ve demografik özellikleri, geçirilmiş suçiçeği öyküsü veya suçiçeği aşısı, tetikleyici faktörler ve komplikasyonlar retrospektif olarak incelendi. Hastaların 28'i kız (\%50,9) ve 27'si erkekti (\%49,1). Yaş ortalaması $10,16 \pm 4,1$ idi. En sik tutulan dermatomlar; torakal $(\% 52,7)$, servikal $(\% 12,7)$ ve sakral $(\% 9,1)$ bölgeydi. En sık saptanan semptom yanmabatma hissiydi $(\% 43,6)$. Sadece bir olgunun suçiçeği aşısı vardı. Sadece 2 olguda sekonder bakteriyel enfeksiyon saptandı. Hiçbir hasta postherpetik nevralji geliştirmedi. Herpes zoster çocuklarda nadir görülen bir hastalıktır. Çocukluk çağında görülen herpes zosterin kliniği ve prognozu erişkinlerden farklıdır. Her ne kadar torakal tutulum çalıșmamızda en sık saptanmış dermatom olmakla birlikte çocuklarda servikal ve sakral tutulum da dikkat çekmektedir. Suçiçeği aşışı sonrasında herpes zoster gelişebilmektedir. Sağlıklı çocuklarda iyi seyreden herpes zoster genellikle komplikasyonsuz iyileşmektedir.
\end{abstract}

Anahtar Kelimeler: Çocukluk çağı. Herpes zoster. Suçiçeği aşısı.

Herpes Zoster in Children: A Retrospective Study of 55 Cases

\begin{abstract}
Herpes zoster is an infection caused by reactivation of varicella zoster virus which is latent in dorsal root ganglia. Herpes zoster rarely affects healthy children. It was aimed to investigate the clinical and demographic characteristics of pediatric patients with herpes zoster. 55 children aged 0-16 years who reached to our Dermatology\&Venereology outpatient clinic between December 2014 and December 2016 were included in the study. Clinical and demographic characteristics, history of varicella or varicella vaccine, triggering factors, and complications were evaluated retrospectively. 28 of the patients were girl $(50,9 \%)$ and 27 were boy $(49,1 \%)$. The mean of age was 10,16 $\pm 4,1$ years. The most common dermatomes are; thoracic (52,7\%), cervical $(12,7 \%)$, and sacral $(9,1 \%)$ region. The most common symptom was stinging-burning sensation (43,6\%). Only one patient had varicella vaccination. Only 2 cases had secondary bacterial infection. No patient developed postherpetic neuralgia. Herpes zoster is a rare disease in children. Clinical and prognostic characteristics of herpes zoster in childhood are different from adults. Although thoracic involvement is the most common dermatome in our study, cervical and sacral involvement is also noteworthy in children. Herpes zoster can be seen after the varicella vaccination. Herpes zoster, which has a benign course in healthy children, usually heals without complications.
\end{abstract}

Key Words: Childhood. Herpes zoster. Varicella vaccine.

Varisellazostervirüs (VZV) çift zincirli ve zarflı bir DNA virüsüdür. Primer enfeksiyonu varisella (suçiçeği) olup genellikle çocukluk çağında görülen, bulaşıcı,

Geliş Tarihi: 11.Şubat.2020

Kabul Tarihi: 02.Nisan.2020

* 28. Ulusal Dermatoloji Kongresi'nde (24-28 Eylül 2019, Antalya) poster bildiri olarak sunulmuştur.

Dr. Sinan ÖZÇELIKK

Deri ve Zührevi Hastalıklar Anabilim Dalı, Balıkesir

Üniversitesi Tıp Fakültesi, Balıkesir.

Tel.: +90 2666121010

E-posta: sinozc@gmail.com döküntülü bir hastalıktır. VZV, primer enfeksiyondan sonra, kraniyal sinir ve dorsal kök ganglionlarında yıllarca sessiz kalabilir. Herpes zoster, işte bu dorsal kök ganglionların dalatent halde bulunan varisellazoster virüsün (VZV) reaktivasyonu ile ortaya çıkan bir enfeksiyondur. Virüse özgü immünitedeki değişikliğe bağlı olarak genellikle erişkinlerde ve yaşlılarda görülür. Çocuklarda çok daha az görülen herpes zoster çoğunlukla sekel bırakmadan iyileşir. Ülkemizde pediatrik popülasyonda herpes zosterle ilgili yapılmış az sayıda çalışmanın olgu sayıları da genel olarak azdır. ${ }^{1} \mathrm{Bu}$ çalışma ile herpes zoster tanısı alan pediatrik hastaların klinik ve demografik özelliklerinin araştırılması amaçlandı. 


\section{Gereç ve Yöntem}

15.12.2014 ile 15.12.2016 tarihleri arasinda hastanemiz Deri ve Zührevi Hastalıkları polikliniklerine başvurmuş16 yaş altıherpes zoster tanısı almış pediatrik hastalar hastane otomasyon dosya sisteminden retrospektif olarak incelendi. Literatürdeki benzer çalışmalarla karşılaştırmanın uygunluğu açısından 16 yaş altıpediatrik hastalar çalışmaya dahil edildi. ${ }^{2,3}$ Kamu veya özelde başka bir Deri ve Zührevi Hastalıkları kliniği olmayan tüm ilde bu tarihler arasında 3 . basamak hastanemizin Deri ve Zührevi Hastalıkları polikliniklerine başvurmuş 55 hasta çalışmaya dahil edildi. Hastaların demografik özellikleri, subjektif şikayetleri, lezyonların ortaya çıktığı ay ve lokalizasyonları, suçiçeği geçirme öyküleri, suçiçeği aşısı yapılıp yapılmadığı, tetikleyici faktörler, eşlik eden ek hastalıkları ve komplikasyon gelişimi retrospektif olarak incelendi. Çalışmanın geriye dönük tasarımından dolayı hasta onamı alınmadı. Çalışma Helsinki Deklarasyonu ilkelerine uygun olarak yapıldı. Yerel Etik Kurulu'nun 28.03.2017 tarihli 3/02 sayılı kararı ile izin alındı.

\section{İstatistiksel Çözümleme}

İstatistiksel çalışmalar STATA (versiyon 13) yazılımı ile yapıldı. Sayımla elde edilen veriler sayı ve yüzde ile ölçümle elde edilen veriler ortanca, 25. ve 75. persentil değerleriyle ile ifade edildi.

\section{Bulgular}

Ülkemiz Adrese Dayalı Nüfus Kayıt Sistemi'ne göre çalı̧̧manın yapıldığı ilin 2015 yılı nüfusu 222918 olarak bildirilmiş̧ir. Belirtilen tarihler arasında hastaneye başvuran 0-16 yaş arası 110880 hastanın 55'inin herpes zoster tanısı almış olduğu saptandı.55 olgunun 28 'i kadın $(\% 50,9)$ ve 27 'si erkekti $(\% 49,1)$. Yaş ortalaması $10,16 \pm 4,1$ idi. Kadınların yaş ortalaması $9,46 \pm 3,42$ (ortanca 9 , alt çeyrek ortancası 8 , üst çeyrek ortancas1 12), erkeklerin yaş ortalamas1 $10,88 \pm 4,66$ (ortanca 13, alt çeyrek ortancası 8 , üst çeyrek ortancas1 15) idi (Tablo I). En küçük olgu 2 yaşındaydı. Olguların 32'sinde suçiçeği geçirme öyküsü tespit edildi. Sadece 2 olgunun öyküsünde annenin gebelik sırasında suçiçeği geçirme öyküsü saptanmış olup annesi gebelik sırasında herpes zoster geçiren olgu yoktu. Annesi gebelik sırasında VZV enfeksiyonu geçiren kişilerle aynı ortamda bulunma öyküsü 2 olguda vardı. Sadece 1 olgunun suçiçeği aşısı vardı.
Tablo I. Olguların cinsiyet dağılımı ve yaş ortalamalar1

\begin{tabular}{|l|c|c|c|}
\hline & Sayı & Yüzde (\%) & Yaş ortalaması \\
\hline Kadın & 28 & 50,9 & 9,46 \\
\hline Erkek & 27 & 49,1 & 10,88 \\
\hline Toplam & 55 & 100 & 10,16 \\
\hline
\end{tabular}

Olguların 24'ünde yanma-batma hissi (\%43,6), 9'unda ağrı $(\% 16,4), 9$ 'unda kaşıntı $(\% 16,4), 13$ 'ünde ise herhangi subjektif yakınma yoktu $(\% 23,6)$ (Grafik I).

Lezyonlar olguların tamamında tek bir dermatomdaydı. Lezyonların görüldüğü dermatomların dağılımı; 29 olguda toraks (\%52,7), 7 olguda servikal $(\% 12,7), 5$ olguda sakral $(\% 9,1), 4$ olguda trigeminal $(\% 7,3), 4$ olguda üst ekstremite $(\% 7,3), 4$ olguda lumbal $(\% 7,3)$ ve 2 olguda alt ekstremite $(\% 3,6)$ şeklindeydi (Grafik II). Lezyonlar 30 olguda sağ tarafta $(\% 54,5), 25$ olguda sol tarafta $(\% 45,5)$ yerleşim göstermekteydi.

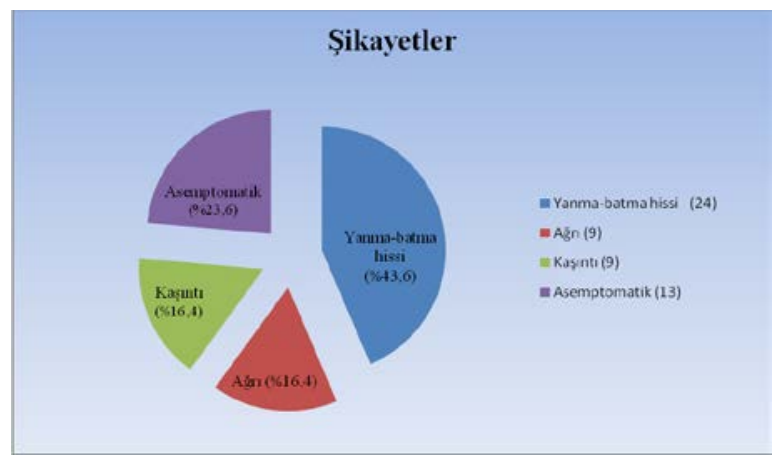

Grafik I.

Subjektif şikayetlerin dağılımı

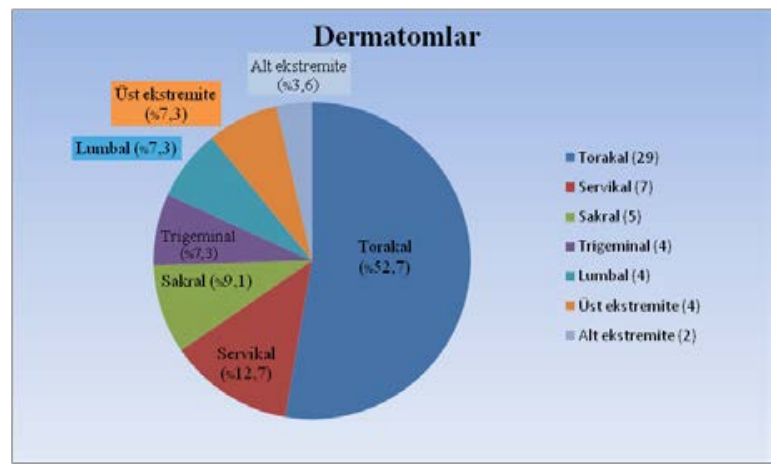

Grafik II.

Tutulan dermatomların dağılımı

Tetikleyici faktörler açısından bakıldı̆̆ında; olguların 13'ünde yakın zamanda geçirilmiş olan üst solunum yolu enfeksiyonu, 7'sinde emosyonel stres saptanmışken 35'inde herhangi bir tetikleyici faktör tespit edilemedi.

Olguların 3'ünde astım, 2'sinde tip 1 diabetesmellitus mevcut olup 50'sinde eşlik eden herhangi bir hastalık yoktu. Komplikasyon gelişimi açısından bakıldı̆̆ında sadece 2 olguda sekonder bakteriyel enfeksiyon ger- 
çekleşmiş olduğu gözlendi. Hiçbir olguda postherpetik nevralji saptanmadi.

Olguların başvuru aylarına göre değerlendirildiğinde; en fazla hasta sayısının Nisan (8 olgu), Kasım (8 olgu) ve Aralık (7 olgu) aylarında olduğu, en az hasta sayısının ise Eylül (2 olgu) ve Ekim (2 olgu) aylarında olduğu görülmüştür (Tablo II). Mevsimsel olarak bakıldığında; en fazla başvurunun ilkbahar (16 olgu) ve kış (16 olgu) mevsimlerinde olduğu bunları sonbahar (12 olgu) ve yaz (11 olgu) mevsiminin takip ettiği görülmüştür.

Tablo II. Olguların başvuru aylarına göre dağılımı

\begin{tabular}{|l|c|c|}
\hline \multicolumn{1}{|c|}{ Ay } & Sayı & Yüzde (\%) \\
\hline Ocak & 4 & 7,3 \\
\hline Şubat & 5 & 9,1 \\
\hline Mart & 4 & 7,3 \\
\hline Nisan & 8 & 14,5 \\
\hline Mayıs & 4 & 7,3 \\
\hline Haziran & 4 & 7,3 \\
\hline Temmuz & 4 & 7,3 \\
\hline Ağustos & 3 & 5,4 \\
\hline Eylül & 2 & 3,6 \\
\hline Ekim & 2 & 3,6 \\
\hline Kasım & 8 & 14,5 \\
\hline Aralık & 7 & 12,8 \\
\hline
\end{tabular}

\section{Tartışma}

Herpes zoster, dorsal kök ganglionlarında latent halde bulunan VZV'nin reaktivasyonu ile ortaya çıkan bir enfeksiyondur. Reaktivasyonun hücresel immünite ile ilişkili olduğu düşünülmektedir ${ }^{4}$. İleri yaş (yaşa bağ $l_{1}$ immun sistem zayıflığı-immunosenescence), hastalık ilişkili immün yetmezlikler (neoplastik hastalıklar, HIV enfeksiyonu...), iyatrojenik immümsüpresyon (immünsüpresif ilaçlar, radyoterapi, cerrahi...) herpes zosterin temel risk faktörleri arasında yer almaktadır ${ }^{4,5}$. Bunların dışında travma, emosyonel stres, diğer enfeksiyonlar gibi herpes zoster gelişimini kolaylaştıran birtakım faktörler de söz konusudur. Bizim çalışmamizda da özellikle üst solunum yolu enfeksiyonu ile emosyonel stres kolaylaştırıcı faktörler olarak dikkat çekmektedir.

Hastalık, virüse özgü immünite kaybına bağlı olarak genellikle erişkinlerde ve yaşlılarda görülür(4, 6). Sağlıklı erişkinlerde insidans 1000 kişide 1,2 ila 3,4 arasında değişmekle birlikte çocuklarda bu oran 0,45/1000 düzeyindedir ${ }^{7,8}$. İmmünsüpresyon herpes zoster için önemli bir predispozan faktör olmakla birlikte pediatrik herpes zoster her zaman karşımıza immün yetmezlik, malignite veya HIV enfeksiyonu ile ilişkili olarak çıkmamaktadır. Çalışmamızda da olgu- larımızın hiçbirinde immünsüpresyona neden olabilecek bir durum söz konusu değildi. İmmünsüpresyona neden olan durumlar açısından hastaların sorgulanmas1 gerekmekle birlikte sağlıklı çocuklarda da gözlenebileceği akılda tutulmalıdır. Her ne kadar astım ile herpes zoster arasındaki ilişki bilinmese de astımlı olgularda herpes zosterin arttığını gösteren birtakım çalışmalar vardır'. Çalışmamızda olguların 3'ünde astım mevcuttu. Literatürde tip 1diabet ile artmış herpes zoster riski arasında ilişki saptayan çalışmalar vardır $^{10}$. Çalışmamızda 2 olguda tip 1 diyabet mevcuttu.

Pediatrik herpes zoster olgularının çoğunluğu in-utero veya yaşamın ilk yılı içinde varisella geçiren veya temas öyküsü olan çocuklardır. Yaşamın ilk yılında varisella geçirenlerde varisella ile herpes zoster arasındaki ortalama süre 3,8 yıl iken, 1 yaş sonrası sonra varisella geçirenlerde ise bu süre 6,2 y1l olarak belirtilmiştir ${ }^{5}$.Çalışmamızda 32 olguda $(\% 58,1)$ suçiçeği geçirme öyküsü mevcut olup 8 yaş altı olguların hiçbirinde suçiçeği geçirme öyküsü yoktu. Sadece 2 olguda annenin gebelik sırasında suçiçeği geçirme öyküsü söz konusu olup bu iki olgu da 2 yaşındaydi. Annesi gebelik sırasında VZV enfeksiyonu geçiren kişilerle aynı ortamda bulunma öyküsü olan 2 olgudan birinin yaşı 3 diğerininki ise 4'tü. Suçiçeği öyküsü alınamayan 23 olgunun enfeksiyonu subklinik veya intrauterin geçirmiş olabileceği düşünülmüştür.

Suçiçeği aşısının yararı yapılan çalışmalarla gösterilmiş olmasına karşın literatürde uluslararası aşılama programlarının herpes zoster epidemiyolojisinde değişiklikler yapabileceği ile ilgili birçok çalışma bulunmaktadır ${ }^{11-13}$. Birçok ülkede rutin aşılama programı çerçevesinde uygulanan suçiçeği aşısı ülkemizde Şubat 2013 itibariyle rutin aşılama programına girmiştir. Suçiçeği aşısı, virüse karşı hücresel bağışıklı̆̆1 artırarak virüs reaktivasyonunu önleyip herpes zoster gelişimini önleyebilir ${ }^{14}$. Bununla birlikte suçiçeği aşısı sonrası herpes zoster gelişebilmektedir. Ülkemizde yapılan bazı çalışmalarda da suçiçeği aşısı sonrası herpes zoster olguları bildirilmiştir ${ }^{1,2}$. Çalışmamızda sadece 1 olguda suçiçeği aşı öyküsü vardı. Suçiçeği aşısının sağlıklı çocuklarda herpes zoster riskini azaltacağı, enfeksiyon gelişse bile iyi seyirli olup olası komplikasyonlara karşı koruyucu olacağını düşünmekle birlikte aşı ile ilgili olarak öncelikle ülkemizde VZV enfeksiyonu özelinde detaylı epidemiyolojik ve klinik araştırmalara ihtiyaç olduğunu düşünüyoruz.

Olguların yaş ortalaması 10,16 olup genel olarak literatürle uyumludur. Ülkemizdeki çalışmalardaki ortalama yaşa bakıldığında; Topkarcı ve ark. ${ }^{15} 8$, Tepe ve ark. $^{16} 9,12$, Çölgeçen ve ark. ${ }^{3} 10,6$, Özuğuz ve ark. ${ }^{2} 8$ olarak belirtmişlerdir (Tablo III). Çalışmamızdaki cinsiyet dağılımında bir cinsiyetin baskınlığı söz konusu olmayıp genel olarak literatürle uyumludur. 
Tablo III. Pediatrik herpes zosterle ilgili ülkemizde yapılımış çalışmalar

\begin{tabular}{|c|c|c|c|c|c|c|c|}
\hline & $\begin{array}{l}\text { Topkarcı ve } \\
\text { ark., } 2012\end{array}$ & $\begin{array}{l}\text { Çölgeçen ve } \\
\text { ark., } 2012\end{array}$ & \begin{tabular}{|c|} 
Şen ve ark., \\
2013
\end{tabular} & $\begin{array}{l}\text { Özuğuz ve } \\
\text { ark., } 2014\end{array}$ & $\begin{array}{l}\text { Tepe ve ark., } \\
2016\end{array}$ & \begin{tabular}{|c|} 
Karagün ve ark., \\
2019
\end{tabular} & Çalışmamız \\
\hline Olgu sayısı (n) & 14 & 24 & 16 & 12 & 31 & 48 & 55 \\
\hline Yaş ortalaması & 8 & 10,6 & 7,3 & 8 & 9,1 & 5,9 & 10,1 \\
\hline Cinsiyet dağılımı (K:E) & $1: 2,5$ & $1,4: 1$ & $1,2: 1$ & $1: 2$ & $1: 1,5$ & $1: 1,1$ & $1: 1$ \\
\hline $\begin{array}{l}\text { En çok gösterilen } \\
\text { semptom, } n(\%)\end{array}$ & $\begin{array}{l}\text { Kaşıntı, } 6 \\
(\% 42,8) \\
\end{array}$ & $\begin{array}{c}\text { Kaşıntı, } 13 \\
(\% 54,2) \\
\end{array}$ & Ağrı, $4(\% 25)$ & $\begin{array}{c}\text { Kaşıntı, } 4 \\
(\% 33,3) \\
\end{array}$ & $\begin{array}{l}\text { Kaşınt, } 15 \\
(\% 48,4)\end{array}$ & \begin{tabular}{|c|} 
Yanma-batma \\
hissi, $39(\% 81,2)$ \\
\end{tabular} & $\begin{array}{c}\text { Yanma-batma } \\
\text { hissi, } 24(\% 43,6) \\
\end{array}$ \\
\hline $\begin{array}{l}\text { En çok tutulan derma- } \\
\text { tom }\end{array}$ & $\begin{array}{c}\text { Torakal, } 9 \\
(\% 64,2)\end{array}$ & $\begin{array}{c}\text { Torakal, } 16 \\
(\% 66,7)\end{array}$ & $\begin{array}{c}\text { Torakal, } 6 \\
(\% 37,5) \\
\end{array}$ & $\begin{array}{c}\text { Torakal, } 7 \\
(\% 58,3)\end{array}$ & $\begin{array}{c}\text { Torakal, } 20 \\
(\% 64,5)\end{array}$ & $\begin{array}{c}\begin{array}{c}\text { Lumbosakral, } 17 \\
(\% 35,4)\end{array} \\
\end{array}$ & $\begin{array}{c}\text { Torakal, } 29 \\
(\% 52,7) \\
\end{array}$ \\
\hline $\begin{array}{l}\text { Suçiçeği geçirme } \\
\text { öyküsü, } n(\%)\end{array}$ & $13(\% 92,8)$ & $19(\% 79,2)$ & $\begin{array}{c}8 \\
(\% 50) \\
\end{array}$ & $\begin{array}{c}6 \\
(\% 50) \\
\end{array}$ & $19(\% 61,2)$ & $\begin{array}{c}20 \\
(\% 41,6) \\
\end{array}$ & $\begin{array}{c}32 \\
(\% 58,1) \\
\end{array}$ \\
\hline $\begin{array}{l}\text { Suçiçeği aşı öyküsü, n } \\
(\%)\end{array}$ & 0 & 0 & $1(\% 6,2)$ & $2(\% 16,6)$ & 0 & 0 & $1(\% 1,8)$ \\
\hline Komplikasyon, n (\%) & 0 & 0 & 0 & 0 & 0 & $2^{*}$ & 2 2* \\
\hline
\end{tabular}

Pediatrik herpes zoster kliniği genel olarak erişkin herpes zosterine benzemekle birlikte birtakım farkl1lıklar söz konusudur. Lezyonların dermatomal yerleşimi, unilateral olup orta hattı geçmemesi her yaş döneminin ortak özellikleridir. Erişkinlerde ön planda olan semptom prodromal ağrı iken çocuklarda kaşıntı, batma-yanma hissidir. Çalışmamızda olguların 24'ünde $(\% 43,6)$ yanma-batma hissi ağırlıklı semptom olarak saptanmışken 9 olguda $(\% 16,4)$ ağrı, 9 olguda $(\% 16,4)$ kaşıntı söz konusuydu. 13 olguda $(\% 23,6)$ ise herhangi yakınma yoktu. Bu durum literatürdeki diğer çalışmalarla uyumlu olarak bulunmuştur ${ }^{3,16-18}$. Bazı yazarlar tarafindan çocuklarda herpes zosterin genellikle servikal vesakral bölgeleri, erişkinlerde ise torakal, lumbal ve trigeminal bölgeyi tuttuğu ifade edilmektedir $^{19}$. Çalışmamızda en sık tutulan dermatom 29 olgu ile torakstı $(\% 52,7)$. Bunu 7 olgu ile servikal $(\% 12,7)$ ve 5 olgu ile sakral bölge $(\% 9,1)$ izlemekteydi. Yaş büyüdükçe tutulum alanları erişkinlere benzemekteydi.

Herpes zoster sağlıklı çocuklarda genellikle 1-3 haftada komplikasyonsuz iyileşir. Herpes zoster için çoğu kez antiviral tedavi gerekmediğini ifade edenler kadar sistemik antiviral tedavi verilmesi gerektiğini söyleyen yazarlar da vardir ${ }^{20}$. Herpes zoster komplikasyonları arasında en sık görülen postherpetik nevralji olup bunun dişında sekonder bakteriyel enfeksiyon, postinflamatuar pigmentasyon değişiklikleri, skar oluşumları, disseminasyon, fasyal paralizi, menenjit, ensefalit gibi komplikasyonlar da bulunmaktadır ${ }^{19}$. Postherpetik nevralji, erişkinlerden farklı olarak çocuklarda çok nadirdir. Çalışmamızda hiçbir olguda postherpetik nevralji saptanmamış olup sadece 2 olguda sekonder bakteriyel enfeksiyon gözlenmişti.

Çalışmamızın kısıtlayıcı yönleri; tek merkezli ve retrospektif bir çalışma olması, uzun dönemde komplikasyonların takip edilememesidir. Çalışmamız her ne kadar tüm ili kapsıyor olsa da sadece poliklinik başvurusu yapmış olguları içermektedir.

\section{Sonuç}

Herpes zoster çocuklarda nadir görülen bir hastalıktır. Sağlıklı çocuklarda genellikle iyi seyreden bu hastalığın gelişiminde annenin gebeliği sırasında veya çocuğun yaşamının ilk yıllarında geçirdiği suçiçeği enfeksiyon öyküsü önemlidir. Ülkemizde rutin aşılama programı içinde olan suçiçeği aşısı herpes zoster gelişimini azaltabilir. Çocukluk çağı herpes zoster kliniği ve prognozunun erişkinlerden farklı olduğu görülmektedir. Bununla birlikte pediatrik herpes zoster çalışmalarında olgu sayıları genellikle azdır. Bu bakımdan herpes zosterin çeşitli yaşlarda klinik farklılıkları, genel olarak hastalığın epidemiyolojisi ve aşılama programlarının farklı yaş gruplarında hastalığın görülme sıklığına etkisi konusunda detaylı araştırmalara ihtiyaç olduğu düşünülmektedir.

\section{Kaynaklar}

1. Şen S, Bayram N, Bal ZŞ, et al. İki çocuk enfeksiyon kliniğinin herpes zoster deneyimi. 2013; 48(1): 40-43.

2. Özuğuz $\mathrm{P}$, Doğruk Kaçar S, Polat $\mathrm{S}$, et al. Çocukluk çağı zona zoster: 12 olgu sunumu. 2014; 3(3): 253-256.

3. Çölgeçen E, Küçük Ö, Balci MJT. Cocukluk Cagi Herpes Zoster Infeksiyonun Klinik Özellikleri/Clinical Features of Herpes Zoster Infections in Childhood. 2012; 46(1): 26.

4. Arvin AMJTJoid. Humoral and cellular immunity to varicellazoster virus: an overview. 2008; 197(Supplement_2): S58-S60.

5. Feder HM, Jr., Hoss DM. Herpes zoster in otherwise healthy children. The Pediatric infectious disease journal 2004; 23(5): 451-457; quiz 458-460.

6. Goldman GS, King PG. Review of the United States universal varicella vaccination program: Herpes zoster incidence rates, cost-effectiveness, and vaccine efficacy based primarily on the Antelope Valley Varicella Active Surveillance Project data. Vaccine 2013; 31(13): 1680-1694.

7. Dworkin RH, Johnson RW, Breuer J, et al. Recommendations for the management of herpes zoster. Clinical infectious disea- 


\section{Çocuklarda Herpes Zoster}

ses: an official publication of the Infectious Diseases Society of America 2007; 44 Suppl 1: S1-26.

8. Katakam BK, Kiran G, Kumar U. A Prospective Study of Herpes Zoster in Children. Indian journal of dermatology 2016; 61(5): 534-539.

9. Wi CI, Kim BS, Mehra S, et al. Risk of herpes zoster in children with asthma. Allergy and asthma proceedings 2015; 36(5): 372-378.

10. Chen HH, Lin IC, Chen HJ, et al. Association of Herpes Zoste and Type 1 Diabetes Mellitus. PloS one 2016; 11(5): e0155175.

11. van Hoek AJ, Melegaro A, Zagheni E, et al. Modelling the impact of a combined varicella and zoster vaccination programme on the epidemiology of varicella zoster virus in England. Vaccine 2011; 29(13): 2411-2420.

12. Reynolds MA, Chaves SS, Harpaz R, et al. The impact of the varicella vaccination program on herpes zoster epidemiology in the United States: a review. The Journal of infectious diseases 2008; 197 Suppl 2: S224-227.

13. Thomas SL, Wheeler JG, Hall AJ. Contacts with varicella or with children and protection against herpes zoster in adults: a case-control study. Lancet (London, England) 2002; 360(9334): 678-682.

14. Kimberlin DW, Whitley RJJNEJoM. Varicella-zoster vaccine for the prevention of herpes zoster. 2007; 356(13): 1338-1343.

15. Topkarcı Z, Erdoğan B, Erkum T, et al. Sağlıklı çocuklarda herpes zoster infeksiyonu. 2012; 8(4): 178-181.

16. Tepe B, Bucak İH, Almış HJTJoDTDD. Sağlıklı Çocuklarda Herpes Zoster: Retrospektif Bir Çalışma. 2016; 10(2).

17. Karagün EJTJoDTDD. Çocukluk Çağı Herpes Zoster Enfeksiyonu: Retrospektif Çalışma. 2019; 13(1).

18. Mitra B, Chopra A, Talukdar K, et al. A Clinicoepidemiological Study of Childhood Herpes Zoster. Indian dermatology online journal 2018; 9(6): 383-388.

19. Leung AK, Robson WL, Leong AG. Herpes zoster in childhood. Journal of pediatric health care : official publication of National Association of Pediatric Nurse Associates \& Practitioners 2006; 20(5): 300-303.

20. Sawant SP, Amin AS, Kumar SJPID. Herpes zoster in a healthy immunocompetent two-year-old child. 2012; 4(1): 13-14 
